\title{
THE LEADERSHIP STRATEGY OF THE SCHOOL PRINCIPAL IN IMPROVING TEACHERS' PERFORMANCE IN SMA MUHAMMADIYAH 4 SURABAYA
}

\author{
Siti Mariyati ${ }^{1}$ Zainuddin Maliki $^{2}$ \\ Sitimariyati36@gmail.com¹ zainuddin_M@gmail.com²
}

\begin{abstract}
Muhammadiyah 4 Surabaya is a school continually experienced various developments including in an effort to improve the performance of the teachers. SMA Muhammadiyah 4 Surabaya is a religion-based school in Karangpilang which experiences increasing number of students and community interest from year to year. It cannot be separated from the strategy and active role of the principal. This study aims to find out and explore what is the leadership strategy of school principals in improving teachers' performance in SMA Muhammadiyah 4 Surabaya? And what are the supporting factors and obstacles of school principals in improving teachers' performance in SMA Muhammadiyah 4 Surabaya? This is a qualitative research with descriptive approach. The process of data collection is done by using observation, interview and documentation. Data are collected and analyzed through several stages including data collection, reduction, and presentation then drawing conclusions in accordance with the scope of the problem. As the findings of this study, it can be concluded that: First, Principal Leadership Strategy in improving teacher performance in SMA Muhammadiyah 4 Surabaya consists of 9 strategies. Second, the supporting factors in this school environment consist of 3 factors and the inhibiting factors consist of 2 factors. The supporting factors are teacher education level, conducive climate, and mental condition of the teachers. The inhibiting factors are caused by internal and external factors. The internal factor is budget limitation while the external factor is the parents' financial conditions.
\end{abstract}

Keywords: Strategy, Leadership, Teachers’ Performance

\section{A. Introduction}

The school principal as the top leader has the authority and power of lead to effectively regulate and develop his subordinates in a professional manner. The principal as a leader, with his leadership role, has the greatest responsibility for the lead agency because the principal is an important factor influencing the failure or success of an institution. ${ }^{1}$

The principal is one of the most decisive components of education in improving the quality of education. The principal as a leader of an educational institution in its leadership activity must have professional competence, including (1) principal as leader, (2) principal

\footnotetext{
${ }^{1}$ Sukamto, kepemimpinan kyai dalam pesantren, (Jakarta: Lp3S, 1999), 19.
}

as manager, (3) principal as educator, (4) principal as administrator, (5) principals as entrepreneurs, (6) principals as creators of work climate, and (7) principals as providers. $^{2}$

In the constitution of the republic of Indonesia number 20 year 2003 about national education system, the meaning of education is a conscious and planned effort to create an atmosphere of learning process so that learners actively develop their potential to have spiritual power, self-control, personality, intelligence, good character, and skills needed by society, nation and state. ${ }^{3}$

\footnotetext{
${ }^{2}$ Standart kompetensi kepala sekolah TK, SD, SMP, SMA, SMK dan SLB, (Yogyakarta: Pustaka Yustisia, 2007), 102-104.

${ }^{3}$ National education department of RI, Undang-
} 
Furthermore, in the constitution of the republic of Indonesia number 20 year 2003 about the national education system, article 3 states that the national education functions to develop the ability and forms the character and civilization of a dignified nation in order to educate the nation life, aims to the development of potential learners to become devout and pious human to Allah have noble attitudes, healthy, smart, skillful, creative, independent, democratic, and responsible. $^{4}$

In the constitution number 14 year 2005 on teachers and lecturers, article (1) mentions that teachers are professional educators with the main task of educating, teaching, guiding, directing, training, assessing, and evaluating learners in early childhood education formal education path, primary and secondary education. Incompetence of a teacher in delivering teaching materials in the learning process indirectly affects the learning outcomes.

The learning process can be achieved with a good teachers' personal competencies. Limitations of knowledge in delivering materials both in terms of the use of teaching methods and other key learning supporting books will affect the learning outcomes. Efforts are made to improve teachers' performance through the MGMP, teacher working group (KKG) and other trainings in both their respective fields of study and other matters that can improve teacher professionalism.

The principal is essentially a teacher who is given an additional

Undang RI Nomor 20 Tahun 2003 Tentang Sistem Pendidikan Nasional (Jakarta : Departemen Pendidikan, 2003), Cet.I, 6.

${ }^{4}$ Ibid. assignment. The principal is one of the most important components of education in improving the quality of education. Mulyasa explains that: "there is a close relationship between the quality of principals and various aspects of school life such as school discipline, and school climate". The principal must be able to create a conducive and innovative atmosphere in carrying out activities at school. ${ }^{5}$

This is in accordance with the ministry of national education regulation no. 13 year 2007 on principal/ Madrasah Standards which states that "principals manage teachers and staff in optimum utilization of human resources, create a conducive and innovative school culture and climate for learning".

The principal must have vision, mission, creative and innovative and quality oriented. This strategy is a systematic effort of the principal continuously to improve the quality of service so the focus is directed to teachers and other education personnel so that the educational institutions runs well.

In the regulation of the ministry of national education of the republic of Indonesia number 13 year 2017 on the principal standards states that principals must have qualifications and competencies. ${ }^{6}$ The qualifications consist of general qualifications and special qualifications. General qualifications include (1) having academic qualification of undergraduate or diploma four (D-IV) of education or non-education at an accredited

\footnotetext{
${ }^{5}$ Mulyasa E, Manajemen dan kepemimpinan kepala sekolah, (Jakarta: Bumi Aksara, 2005), 24.

${ }^{6}$ Government regulation No.13 year 2017 on the standard of school principal
} 
university; (2) At the time of appointment as a headmaster aged as high as 56 years; (3) Have at least 5 (five) years of teaching experience according to their respective school level, except in kindergarten/ Raudhatul Athfal (TK/ RA) having at least 3 (three) years of teaching experience in TK/ RA; and (4) Have a rank as low as III/ c for civil servants (PNS) and for non-civil servants equal to the rank issued by the foundation or authorized institution.

Special qualifications for high school principals consist of (1) being a high school/ MA teacher; (2) Having a certificate of educator as a teacher of SMA/ MA; and (3) Having a high school principal certificate/ MA issued by a government agency.

The regulation of the minister of national education of the republic of Indonesia number 13 year 2017 on the principal standards that the principal must have qualifications and competence. This competence is intended as competence dimension consisting of (1) personality; (2)

Managerial; (3) Entrepreneurship; (4) Supervision; and (5) Social. (These competencies can be seen in Appendix 1.A). ${ }^{7}$

As a leader, the principal must also have appropriate strategies to provide motivation to the teacher in carrying out its duties and functions. This motivation can be grown through good environmental arrangements, conducive atmosphere arrangements and communicative, synergistic discipline among components of the school community.

Wahjosumidjo explains that the role of headmaster as a leader is

${ }^{7}$ Ibid. responsible for mobilizing all school resources, controlling the activities of teachers and staff, examining issues within the school environment to generate work ethic and ultimately improve the performance of teachers and staff. A principal must have the ability to mobilize all school resources including teachers. ${ }^{8}$

From this explanation can be seen the principal has the authority to be able to empower resources including teachers in order to be able to perform their duties properly appropriate and in accordance with established school goals.

SMA Muhammadiyah 4 Surabaya is a school that continually experiences various developments including efforts to improve the teachers' performance. SMA Muhammadiyah 4 Surabaya is a religion-based school in Karangpilang which experiences increasing number of students and community interest from year to year. This school also experiences growth and significant improvement of its achievements in the field of knowledge, religion both extracurricular and extracurricular

From this description, the researcher is interested to examine what strategies used by the principal in improving teachers' performance in SMA Muhammadiyah 4 Surabaya

\section{B. Research Methods}

This research uses a qualitative research method. This is because this study aims to naturally investigate how the various processes and realities occurred in the field. According to Sugiyono, in qualitative

\footnotetext{
${ }^{8}$ Wahjosumidjo, Kepemimpinan Kepala Sekolah Tinjauan Teoritik dan Permasalahannya Ed.1 Cet.3. (Jakarta: Raja Grafindo Persada), 2002, 90.
} 
research, researcher plays as human instruments and collects the data through participant observation and in depth Interview, then researchers must interact with data sources. Thus, qualitative researcher should know the person who provided the data. ${ }^{9}$

Researcher uses qualitative method with descriptive approach. According to Sugiyono, descriptive qualitative method is to analyze data by describing the collected data without intending to make conclusions applied to public or generalization. ${ }^{10}$ Qualitative method presents directly the nature of the relationship between researchers and informants, research objects and subjects.

According to Bogdan and Biklen in Sugiyono, Qualitative research has several traits as follows: 11

1. Researcher as the main instrument to directly visit the data source.

2. The collected data in this study Implemented in the form of words than numbers.

3. Explain that the results of research more emphasis on the process rather than the results.

4. Through inductive analysis, the researcher reveals the meaning of this circumstances.

5. Express the meaning of the essentials of the qualitative approach

The central aspect in this research is what strategy used by principals to support teacher

\footnotetext{
${ }^{9}$ Sugiyono, Metode Penelitian Kuantitaif Kualitatif Dan $R \& D$, (Bandung: Alfabeta $\mathrm{Cv}$, 2011), 11

${ }^{10}$ Ibid.

${ }^{11}$ Ibid.
}

performance. The leadership strategy used by principal to support the performance of teachers become the scope of research including the mechanism or rules applied in SMA Muhammadiyah 4 Surabaya. The research is conducted at SMA Muhammadiyah 4 Surabaya at Jl. Kemlaten Baru No. 43 Surabaya.

This research uses data source both primary and secondary source. Primary data sources are the main data that became central in this study. The primary data source in qualitative approach research is certainly derived from informants and research participants in the field and the results of various instruments in this research. The research participants are the principal, vice principal for curriculum, vice principal for infrastructure, vice principal for student affairs, counseling and Teachers.

As supporting data, secondary data source from various literature review is used. Literature review from various sources are both theory and expert opinions used the foundation in the study. In addition, secondary data sources are school documents such as the geography of schools, school profiles, school programs etc.

Data collection techniques in this study include:

1. Observation

Observation as a data collection technique has specific characteristics compared other techniques (interviews and questionnaires). If interviews and questionnaires always communicate with people, then observation is not limited to people, but also other natural objects. According to Sutrisno Hadi in Sugiyono, observation is a complex process, a 
process composed of various biological and psychological processes. Two of the most important are the processes of observation and memory. ${ }^{12}$

This type of data collection technique is typically possessed and applied to a qualitative approach. This method is used to obtain data relating to principal leadership strategy in increasing teacher performance at SMA Muhammadiyah 4 Surabaya. Researcher comes to school to do observations in the school by agreement given by principal of SMA Muhammadiyah 4 Surabaya. This is done to obtain more accurate data of principal leadership strategy in increasing teacher performance at SMA Muhammadiyah 4 Surabaya.

2. Interview

Interviews in data collection are used as reinforcement factors of the data from observation. Interview is conducted to participants involved in this research. One of the participant interviewed by the researcher is Zainal Arifin, M.Pd.I. as the headmaster. This interview is aimed to identify and explore data about teacher performances.

This is done in order to obtain data in accordance with the needs of the research and the achievement of the feasible data used in this study. The results of questions asked to several participant becomes the data to be analyzed in accordance with the research needs.

3. Documentation

Documentation data collection is done in order to increase the use of existed data. Then, the data is also

12 Ibid. documented as material in this research for further analysis. Documentation is done in order to find the need for data in written form to be documented.

Data analysis in this research is done during the research process as the characteristic of qualitative research. However, as Miles and Huberman in Haris Hardiansyah states that the collected data will be process in several stages as follows: ${ }^{13}$

a. Data reduction: done by selection, simplification, and abusing raw data appeared in the field. This process is done continuously throughout the study in accordance with the research conceptual, study issues, and selected data approach.

b. Data Presentation: the collected information is previously reduced to provide possible conclusions and data retrieval. As is widely used in qualitative research, the presentation of data is done by narrative text. However, it should be noted that researcher is constantly matching with the actual state of the field given the occurred changes. This is because the complex and dynamic social phenomenon so the change can be occurred in the field and after a long time occurred changes and development of data.

c. Conclusions: This is also done continuously. This is done by starting from the rough and general indicative to the detailed in accordance with existing in the field. Surely, this is done continuously from the beginning

\footnotetext{
${ }^{13}$ Herdiansyah Haris, Metodologi Penelitian Kualitatif untuk Ilmu-Ilmu Sosial, (Jakarta: Salemba Humanika, 2012), 67.
} 
in the field.

\section{Research Results and Discussion}

1. Strategies implemented by principals in improving teachers' performance of SMA Muhammadiyah 4 Surabaya

In improving teachers' performance, the research in center for leadership studies, Hersey has revealed that principals generally have a major leadership strategies seen as the most frequently behavioral pattern applied in influencing other people activities. In other words, principals generally tend to have a favorite leadership model. ${ }^{14}$

According to Mulyasa, leadership strategy is a specific behavior pattern of a leader in influencing his subordinates including what the leader chooses to do, how the leader acts in influencing group members to form his leadership strategy. ${ }^{15}$

The principal leadership at SMA Muhammadiyah 4 Surabaya has 9 strategies in improving teachers' performance. These 9 strategies are:

1) Creating harmonious conditions in the work place.

Creating harmonious

conditions is the first step of the strategy used by the principal in terms of improving teacher performance. Treating everyone with respect, and being more active listening is a strategy applied in this school. Acknowledgments are also

\footnotetext{
${ }^{14}$ Hersey at al, Management of organizational Behavior: Utiliizing Human resource Englewood Cliffs, (New Jersey L PrenticeHall.1977), 48

${ }^{15}$ Mulyasa, Manajemen Berbasis Sekolah : Konsep Strategi dan, Implementasi,: (PT Remaja Rosdakarya, Bandung,2002), 108
}

often given and used by the principals in listening to advices and suggestions from each subordinate. These are the results of interviews conducted by researcher at high school principals.

Sometimes, through words, we hurt someone or make mistakes either intentional or unintentionally spoken. Apologies are also often heard in this school. The principal explains that the word 'forgiveness' spoken with sincerity can restore a relationship and a bad atmosphere. But sometimes many still have a high ego and assume that by asking apologize will look low, while in fact, by asking for apologize it shows that we are a person who has a high tolerance and maturity. So, many relationships are restored and be better when apologies for the mistakes are asked sincerely from the heart.

2) Developing good cooperation among teachers

A good collaboration between educators is the second strategy undertaken by the principals in improving teachers' performance. Teachers consist of teachers, class-teacher, head of skill program and counselling teacher. Educator profession in the education at any level is always interdependence in carrying out their daily duties. All that requires good cooperation between teachers, class-teachers, head of expertise programs, and counseling teachers (BK).

The vice principal of ISMUBA (al-ISlam, MUhammadiyah, Bahasa arab) gives a statement that the coordination of the program activities in the school in an integrated, harmonious, and 
dynamic is done by educators. All educators are habituated to do "7 S" (Senang (happy), Senyum (smile), Sapa (greeting), Salam (greetings), Salaman (hand-shaking), Sopan (polite), Santun (kind)). The availability of facilities, infrastructure, manpower and things ease the program activities supported by a comfortable, safe, and flexible workplace for all educators. Creating a sense of kinship through teachers' tadarling (tadarus by-turns).

Counselling teachers (BK) states that evaluate students/ class problems and solve it together with teachers, vice principals, BK etc., as well as having regular meeting will bring positive impact on every circumstance happened in the school by discussing problems faced by teacher and employees with sharing methods.

3) Providing rewards and punishment in handling the human resources

The reward and punishment system is given based on performance appraisal. Schools have policies and define how they are used to assess the performance of teachers and employees, for example, using a balanced score card. The results of performance appraisal in the form of numbers make it easier for schools to provide rewards and punishment system to teachers and employees.

This reward is very important to improve the professionalism of educational staff. Through awards can be attributed to the achievement of educational personnel openly, so they have the opportunity to achieve it. ${ }^{16}$

The English teacher explains that the award given by the principal is not only material, but also a mental support to continue to develop our potential. This is a form of appreciation from the headmaster who indirectly pay attention to our performance achievement.

Different questions are asked to the mathematics teachers related to the punishment policy. The teacher explains that as long as he knows that there is no administrative punishment for the undisciplined one in performing the task, the principal only calls the teacher and invites him to speak in private.

4) Human Resource Development Program

Teacher is a factor that determines the success of learning program in the school so teachers are required to have a professional ability in performing their duties. Therefore, the development of the resources/ potentials of the teachers should always be done.

The principal explains that human resource development is always implemented to maximize the MGMP program (subject teachers consultative) according to the field of study, inviting competent speakers in every school activity, providing facilities and infrastructure that facilitates the human resource profession so that the potential can be optimized and synchronized with the school work program as the completion and optimization of the potential human

\footnotetext{
${ }^{16}$ E. Mulyasa, Menjadi Kepala Sekolah

Profesinal, (Bandung: PT Remaja

Roskardaya,2007), 120.
} 
resources.

The same opinion is also conveyed by the vice principal for students' affair that, in principle, every school activity is always supported by the principal. One such activity is academic activities. This activity is an annual event always followed by teachers, for example, Olycon (Olympics and Education Conference of Muhammadiyah) at the University of Muhammadiyah Malang. In another occasion the school also invites competent and experts speakers in curriculum 13. The curriculum 13 is intended for teachers to apply the contents of the curriculum.

In doing their duties teachers are also required and recommended to develop the ability of IT (Information and Technology). This is due to the existence of an official regulation requiring teachers to fill out online report cards. Creating RPP (lesson plan) and questions are also one of the teachers' efforts in developing IT skills.

Heru Bin Ahisetiawan as the IT staff in SMA Muhammadiyah 4 Surabaya explains that in this era, teachers actually also need IT skills. An IT training on educational staff is held to maximize the IT ability in the development era. Peer learning system also helps the development of teachers' ability of IT. Young teachers who generally mastering IT help the senior teachers who do not yet understand IT.

5) Provides opportunities for educators to continue further studies

Motivation is an element of interest in human beings that play a role in achieving success in the business or individual work. According to Stoner, motivation is defined as causal factors that connect with something in a person's behavior. ${ }^{17}$ One of the motivations always given by the principal to the teachers is to continue further studies.

The principal explains that, in general people, who have higher education will have broader insights. So the principal always encourages teachers and subordinates to continue the study, if there is a chance.

On the other hand, the vice principal of ISMUBA explains that until now the principal always give morally appeal and motivation to each worker to develop education and develop themselves. One of the efforts made by the principal always encourages all teachers to continue their studies.

6) Opening recruitment in accordance with the needs

The position of educators is adjusted in accordance with the educational background and the certificate that has been recognized as a standard of professionalism. This is one efforts made by the principal in improving teachers' performance.

The principal, in this case, explains that educators can improve professionalism and is expected to become a capable educator and qualified according to field of knowledge so it will impact on work productivity.

Work productivity is the result of work in quality and quantity achieved by a person in

${ }^{17}$ J.A.F Stoner, Manajemen, Jakarta, PT.

Prenhalindo, 1996, 440 
carrying out his duties in accordance with the responsibilities given to him.

According to the vice president of curriculum, teachers' work productivity can be viewed from teachers' tasks as stated in the main task and function of the teacher. The types of teacher duties as stated in government regulation number 74 year 2008 regarding to teacher article 52, including: (1) learning planning; (2) learning implementation; (3) assessing learning outcomes; (4) guiding and training students; and (5) performing additional tasks. Teachers' duties are based not only on government regulation no. $74 / 2008$ on teachers article 52, but in developing their skills and knowledge, teachers are now required to conduct research, especially classroom action research (PTK), training and workshops, and the development of instructional media.

7) Cooperation with external parties In improving teachers' performance, the principal always have innovation in every step. One of the efforts made by the principal is to work with external parties. External parties, in this case, are defined as companies/ institutions outside the school. These institutions/ companies including BNN, Puskesmas, Campina ice cream cooperation etc.

According to the principal, the policy has been implemented as a real action in line with the applicable curriculum. One of them is PKWU subject. This subject holds a comparative study (practitioner study) at an ice cream company that we have established the product cooperation with the school cooperative.

The vice principal for students' affair explains that every semester the crew of Puskemas (health center) attends to the school. The crew examines students of SMA Muhammadiyah 4, one of which was the examination of Anemia (for female students), ENT, eyes, teeth, and skin. Students affected by the disease are given medication and advised to go to the Puskesmas with regular medication.

According to the staff of ISMUBA, ramadhan program is routinely held in school every ramadhan month. Ramadhan program is held to improve the faith and taqwa as well as the momentum reminding students

about the dangers of drugs. The speech is directly delivered by the BNN (national anti-narcotics agency) of East Java region. On this

occasion the Puskesmas also has opportunity to deliver the material

with the theme of "fasting in the perspective of health".

\section{8) Increasing discipline of human resources}

In leadership, discipline should be interpreted as "educating for improvement and getting better". Discipline, in this case, is not defined as punishment for the guilty, but it is a discipline or guidance to motivate, behave, and perform consistently. Discipline is not only applied when a person is found guilty, but begins in normal working conditions to improve commitment and performance.

The principal explains that the discipline in work is very important for all people in school because it will affect the 
productivity of employees. Good work discipline reflects the extent of a person's sense of responsibility for the tasks assigned to him. Discipline indicates a condition or attitude of respect that exists in every human being to the rules and the accuracy of the organization.

According to vice principal of curriculum, a teacher who has a high level of discipline will still work well even without being supervised by the principal. A disciplined teacher will not steal the work time to do other things that have nothing to do with work.

9) Facilities and Infrastructure Development

One aspect that should be the main concern of every educational manager is the educational facility.

Educational facilities can basically be grouped into four groups: land, buildings, equipment, and school furniture (site, building, equipment, and furniture). In order to make these facilities contributes significantly to the course of the education process, it should be well managed

This management is intended for the use of educational facilities (facilities and infrastructure) in schools run effectively and efficiently. Management of facilities and infrastructure is a very important activity in schools, because its existence will greatly support the success of the learning process in school. In managing the facilities and infrastructure in schools requires a process as contained in the existing management in general, ranging from planning, organizing, mobilization, maintenance and supervision. What is needed by the school needs to be carefully planned with regard to facilities and infrastructure supporting all learning process.

The principal explains that each subject has a different character than the other. Each subject also requires different learning tools. In conducting the learning, of course, the teacher needs a tool that can support its performance so that learning can run interestingly. With the support of adequate learning facilities, teachers not only deliver the material orally, but also by writing and demonstration in accordance with the infrastructure providing in the school.

According to the vice principal for infrastructure, the efforts undertaken by schools are in accordance with the needs of school programs and compliance based on priority/ gradual as needed.

2. Supporting and constraining factors faced by principal in improving teacher performances.

A. Supporting factors are done by the principal as follows

1) Teacher education level factor Teacher education level will greatly affect the quality of teachers' performance. The teachers' ability is very influenced by the level of education, because through education, a person experiencing the learning process from unknown to known, from unable to be able. During educational process a person will receive a lot of input in the form of science and skills affected on their mind and behavior. This means that the higher level of education, the more knowledge and skills learn by 
a person. Thus, the performance is likely to be good because it is supported by the provision of skills and knowledge gained.

2) Conducive situation

Conducive situation in schools will also affect the performance of teachers, including: good classroom management that refers to the arrangement of people (students), as well as the arrangement of facilities (ventilation, lighting, seating, and teaching media). In addition, a good personal relationship between school principals, teachers, students and school employees will create a fun school atmosphere and is one source of passion for teachers in performing their duties.

3) Teachers' physical and mental condition

If the teacher wants to have a good performance, it must be supported by good physical and mental condition as well. A healthy teacher will be able to accomplish his tasks well. Therefore, the health factor must be really paid attention. So does the mental condition of the teacher, when his mental condition is good, he will teach well too.

B. Inhibiting factors faced by principal in improving teacher performance

1) Internal Factor

a) Limited funds

b) Budget funds are limited because students still have not paid the payment to school, for example: tuition fees.

2) External Factors

a) The student's economic factor

b) Parents have not facilitated the needs of children in accordance with the needs of the school. On the other hand, less parental respect of learners have an impact on the school programs inhabitation. For example, when students follow additional lessons of learning, Extras and other activities. Parents assume that the program is unimportant and the most important program is the school subjects.

\section{Conclusions}

From the description that researcher has described, then there are some conclusions taken as an answer to answer the formulated problems as follows: there are 9 strategies used by the principal of SMA Muhammadiyah 4 Surabaya in the process of improving teachers' performance. These strategies are: creating harmonious conditions in the workplace, developing good cooperation among the educators, providing rewards and punishment in facing the human resources, holding human resource development program, providing opportunities for educators to continue further studies, placing recruitment in accordance with the needs, having coordination with external parties, increasing discipline on human resources, and developing facilities and infrastructure.

1.Supporting Factors and Inhibiting Factors in improving teacher performance at SMA Muhammadiyah 4 Surabaya. Supporting factors of teacher performance consists of 3 elements including teacher education level, conducive situation, and mental condition of the teacher.

2.Inhibiting factor of teacher performance consists of 2 factors. These factors include internal factors and external factors. Internal factors are influenced by the limited 
budget. Budget funds become limited because students still have not paid the school payment, for example: the tuition fees. External Factors influenced by the student is economic factor. Parents have not facilitated the needs of children in accordance with the needs of the school, on the other hand, less parental respect to learners have an impact on the school program inhabitation, for example, when students follow additional lessons of learning, Extras and other activities. Parents assume that the program is unimportant and the most important program is the school subjects.

\section{References}

Ahmad Mushtafa Al-Maraghi, TerjemahTafsir Al-Maraghi, Semarang: CV. Toha Putra, 1986.

Anwar, Moch. Idochi. Administrasi Pendidikan dan Manajemen Biaya Pendidikan: Teori Konsep dan Isu, Bandung: Alfabeta, 2004.

Chayyi Fanani, dkk, Panduan Penulisan Skripsi, Surabaya : Fak. Agama Islam UNSURI, 2009.

Daryanto, Adminstrasi Pendidiakan, Jakarta: PT Rineka Cipta, 2006.

Department of religoius affair of RI, The Holy Qur'an Al Fatih, Jakarta: Alfatih, 2009.

Department of the national education of RI, Undang-Undang RI Nomor 20 Tahun 2003 Tentang Sistem Pendidikan Nasional, Jakarta: Department of Education, 2003.

Department of the national education,
Penilaian Kinerja Guru, Jakarta, Dirjen PMPTK, 2008.

Heidjarachman dan Husnan Suad, Manajemen Persoanalia, Yogyakarta: BPFE, 2000.

Herdiansyah Haris, Metodologi Penelitian Kualitatif untuk Ilmu-Ilmu Sosial, Jakarta: Salemba Humanika, 2012.

Ishaq, Yusrizal, Bahrun, Kepemimpinan Kepala Sekolah Dalam Meningkatkan Kinerja Guru Pada Sma Negeri 4 Wira Bangsa Meulaboh Dan Sma Negeri 3 Meulaboh, Jurnal ISSN 2302-0156.

Imam Suprayoga, Revormulasi Visi Pendidikan Islam, STAIN Malang. 1999.

J.A.F Stoner, Manajemen, Jakarta: PT. Prenhalindo, 1996.

Muhamad Asif Ibadulloh, Strategi kepala madrasah dalam meningkatkan kinerja guru di mts ma'arif rohmatullah cokro grabag magelang tahun pelajaran 2010/2011, Skripsi, Sekolah Tinggi Agama Islam Negeri Salatiga tahun 2011.

Mujamil Qomar, Manajemen Pendidikan Islam; Strategi Baru Pengelolaan Lembaga Pendidikan Islam, Jakarta: Erlangga, 2007.

Mukhtar, Strategi kepala sekolah dalam meningkatkan kinerja guru pada smp negeri di kecamatan masjid raya kabupaten aceh besar, Jurnal ISSN 2302-0180.

Mulyasa E, Manajemen Berbasis Sekolah, Bandung: PT.Remaja Rosda Karya, 2004. , Menjadi Kepala Sekolah 
Profesinal, Bandung: PT Remaja Roskardaya,2007.

Manajemen dan kepemimpinan kepala sekolah, Jakarta: Bumi Aksara, 2005.

Moch. Idochi Anwar, Adminstrasi Pendidikan Dan Manajemen Biaya Pendidikan: Teori Konsep dan Isu,Bandung: Alfabeta, 2004.

Moh. Uzer Usman, Menjadi Guru Profesional Manajemen Teori, $\quad$ Bandung: Roskardaya, 1995.

Mujamil Qomar, Manajemen Pendidikan Islam; Strategi Baru Pengelolaan Lembaga Pendidikan Islam, Jakarta: Erlangga, 2007.

Nanang Fatah, Landasan Manajemen Pendidikan, Bandung: PT.Remaja Roskardaya, 2000.

Ngalim Purwanto, Admnistrasi dan Supervisi Pendidikan, Bandung; PT Remaja Roskardaya, 2004.

pendidikan,(Bandung:

Remaja Karya, 1986.

Nur Alimah, Upaya kepala sekolah dalam meningkatkan kinerja guru smp negeri di kecamatan gondokusuman Yogyakarta, Skripsi, Universitas Negeri Jogjakarta tahun 2013.

Government regulation number 13 year 2017 on the standard of school principal

Saiful Sagala, Administrasi Pendidikan Kontemporer, Bandung: CV.Alfabeta,
2000.

Stoner, J.A.F,dkk, Manajemen, Jakarta: PT.Prenhallindo, 1996.

Sukamto, kepemimpinan kyai dalam pesantren, Jakarta: Lp3S, 1999.

Sulistiyorini, Manajemen Pendidikan Islam, Surabaya: el-kaf, 2006.

Suradji, G., \&Martono, E., Ilmu dan Seni Kepemimpinan. Bandung: Pustaka Reka Cipta, 2014.

Standart kompetensi kepala sekolah $T K$, SD, SMP, SMA, SMK dan SLB, Yogyakarta: Pustaka Yustisia, 2007.

Sugiyono, Metode Penelitian Kuantitaif Kualitatif Dan $R \& D$, Bandung: Alfabeta $\mathrm{Cv}, 2011$.

Sukamto, kepemimpinan kyai dalam pesantren, Jakarta: Lp3S, 1999.

Thoha Miftah, Perilaku Organisasi : Konsep Dasar dan Aplikasinya, Jakarta: CV. Rajawali, 1983.

Uci Rahmawati, Upaya kepala sekolah dalam meningkatkan kinerja guru di raudhatul athfal al khairiyah banjarsari kidulkecamatan sokaraja kabupaten banyumas tahun pelajaran 2015/2016, Skripsi, Institut Agama Islam Negeri Purwokerto tahun 2016.

Wahjosumidjo, Kepemimpinan Kepala Sekolah Tinjauan Teoritik dan Permasalahannya Ed.1 Cet.3. Jakarta: Raja Grafindo Persada, 2002. 